Ian Martin

univerza $v$

Edinburghu

\title{
IZOBRAŽEVANJE ODRASLIH IN DISKURZI O DRŽAVLJANSTVU Ekonomski in politični diskurz
}

\section{K} je tudi ta pojem (državljanstvo) lahko del zelo različnih političnih diskurzov, ki se lahko izraža $\mathrm{v}$ različnih političnih okoliščinah (Hall in Held, 1989).

Problem lahko predstavimo $\mathrm{z}$ diagramom:
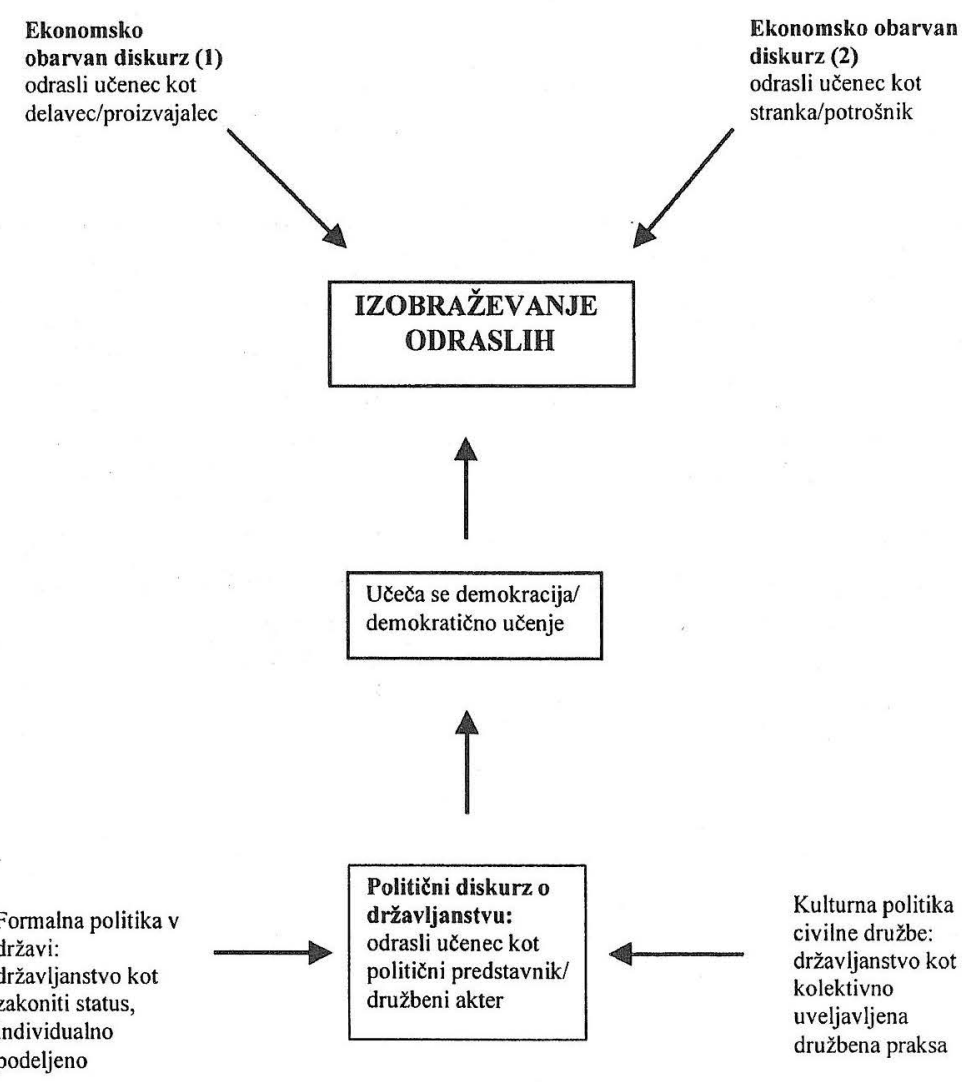

Kulturna politika civilne družbe: državljanstvo kot kolektivno uveljavljena družbena praksa

Opomba: Ta diagram je bil uporablien v uvodnem delu konference 4. edinburškega bienala o izobraževaniu odras lih Izobraževanje odras lih za demokratično obnovo na Škotskem, ki je potekala na univerzi vedinburghu 13. marca 1999.
Kljub zelo razsežni viziji, na primer v Delorsovem poročilu iz leta 1996 Učenje: zaklad v sebi (Delors, 1996) in Fryerjevem poročilu Učenje za enaindvajseto stoletje (Fryer, 1997), so razprave o državljanstvu, ki diskretno obveščajo tudi politično sfero o vseživljenjskem učenju, zasnovane preozko in preveč poenostavljeno, da bi jim uspelo zaobjeti pojem aktivnega državljanstva. Ekonomija »thatcherizma« (zaradi katere še Marxa doživljamo pozitivno) ostaja v Veliki Britaniji nesporna - a tudi precej neopažena. Postala je nekakšna vodilna usmeritev v tem pogledu, da jo doživljamo kot izraz razumnosti oziroma zdravega razuma: delujemo znotraj »diskurzivnih plašnic « in se pri tem vse manj zavedamo, kako nam te zmanjšujejo sposobnost izražanja našega potenciala in odkrivanja možnosti pri delu. Končno smo pri tem, da previdno taktiziramo z lastnimi pogledi in stališči.

Dva diskurza o državljanstvu še vedno močno posegata $v$ naše delo in kraljujeta $v$ naših mislih v zvezi z izobraževanjem, naj bomo izobraževalci ali raziskovalci. Oba diskurza sta po svojem bistvu ekonomsko usmerjena, in sicer tako, da umeščata $v$ središče našega pojmovanja vseživljenjskega učenja predstavo, da so človeška bitja predvsem »ekonomske živali «: naš namen je proizvajati in trošiti (konzumirati) - »imeti « raje kot »biti«. Svet, v katerem živimo, je tržni prostor, kjer so edini odnosi, ki so zares pomembni, materialni odnosi, proizvodnja in izmenjava. 
Prvi, ekonomsko obarvani diskurz postavlja odraslega udeleženca $\mathrm{v}$ izobraževanju na mesto delavca in proizvajalca. Izobraževanje je stroj ekonomske konkurenčnosti na širšem tržišču; brezposelnost in pomanjkanje usposobljenosti sta posledica nerazumevanja tega dejstva. Izobraževanje odraslih se je reduciralo na usposabljanje za delo - pripravo ljudi za njihove vloge $\mathrm{v}$ proizvodnem procesu, ustvarjanje bogastva in dobička (seveda pretežno drugim ljudem). To nekakšno zamegljeno videnje - vse usmeriti v preskrbo - je resnično dojemanje pomena vseživljenjskega učenja. Takšno razmišljanje prevladuje tudi v političnih težnjah. Drugi ekonomsko obarvani diskurz pa postavlja odraslega udeleženca v izobraževanju v vlogo stranke ali kupca. V tem primeru se izobraževanje zreducira na načelo povpraševanja, dobrino, ki jo lahko kupujemo ali prodajamo - z njim trgujemo kot z vsako drugo dobrino. Ta vidik je poudaril znani britanski predstavnik vlade v poznih osemdesetih letih: »Izobraževanje odraslih ne obstaja so le odrasli v razredih. «In tako je izobraževanje odraslih nenadoma zreducirano na tržne transakcije.

To nas prepričuje o tem, da mora izobraževanje za aktivno državljanstvo pomagati ljudem, da prevzemejo najrazličnejše vloge $\mathrm{v}$

Pomena teh ekonomsko obarvanilh diskurzov ne smemo omalovaževati - lahko bi rekli, saj ni pomembno, vendar y resnici je. Ali pa bolje, ni pomenbno za to, kar bi izobraževanje odraslih (tudi če izključimo vseživljenjsko učenje za aktivno državljanstvol moralo biti. Kot izobraževalei nismo le v sluźbi ekonomije ali trgovei na irobraževalnem trgu. Nasprotno, naš interes je usposobiti lúd, da bi popolnoma razvijali svoj potencial, postali scelostne oseber ali dokonèno oblikovana bija. širšem političnem prostoru in se vključujejo $\mathrm{v}$ družbene odnose. Oboje mora potekati zunaj delovnega in tržnega področja. Smo nekaj več kot le ljudje, ujeti v mreži denarja. Ta celovit, državljanski smisel pojmovanja »biti človek « smo vedno imeli v mislih, ko smo jasno in prepričljivo govorili o temeljnih družbenih tradicijah $\mathrm{v}$ izobraževanju odraslih. V vseh obdobjih so ljudje potrebovali tudi »koristno znanje ( kar pomeni vedeti, kaj in kako), da bi lahko skupaj delovali kot državljani (Johnson, 1979). In če si zares želimo ponovno navezati stike ter povezati vseživljenjsko učenje $\mathrm{z}$ aktivnim državljanstvom in družbeno participacijo, je opisana tradicija izobraževanja tista, ki jo moramo obuditi in negovati.

Dobro splošno označbo tradicije in položaja, iz katerega izhaja dosedanje razpravljanje, nam ponuja Keith Jackson (1995). Opisuje tako imenovano angažirano izobraževanje odraslih:

Pogled, ki ga odrasli prinaśajo s seboj, izhaja iz izkušenj njihovega odraslega żivljenja in iz državljanskega statusa, ki ga imajo glede na izobraževalni proces; da je izobraževanje odraslih bolj osnovano na dialogu kot na golem prenašanju znanja in spretnosti, da izobraževanje ni namenjeno le osebnemu razvoju, temveč tudi družbenemu napredovanju, da izobraževa. nje odraslih ustvarja znanje, kar pomeni, da ga ne le posreduje, da so v izobraževanju odraslih dialektiěni in življenjsko pomembni odnosi povezani z družbenimi gibanji.

Iz tega je mogoče potegniti kar nekaj sklepov. Takšni študentje pridejo na izobraževalna srečanja kot "subjekti, ki veliko vedo" in ki že imajo kot državljani določen, nesporen status. Kurikulum je sestavljen, vsaj delno, iz intelektualnih in osebnih virov, pa tudi iz družbenih in političnih interesov, ki jih prinašajo s seboj. Ti ljudje so družbeni akterji - niso prazne posode, deficitarni sistemi, skupki potreb, niti niso, vsaj ne predvsem, proizvajalci in potrošniki. Še več, imajo skupne izobraževalne interese in želje 


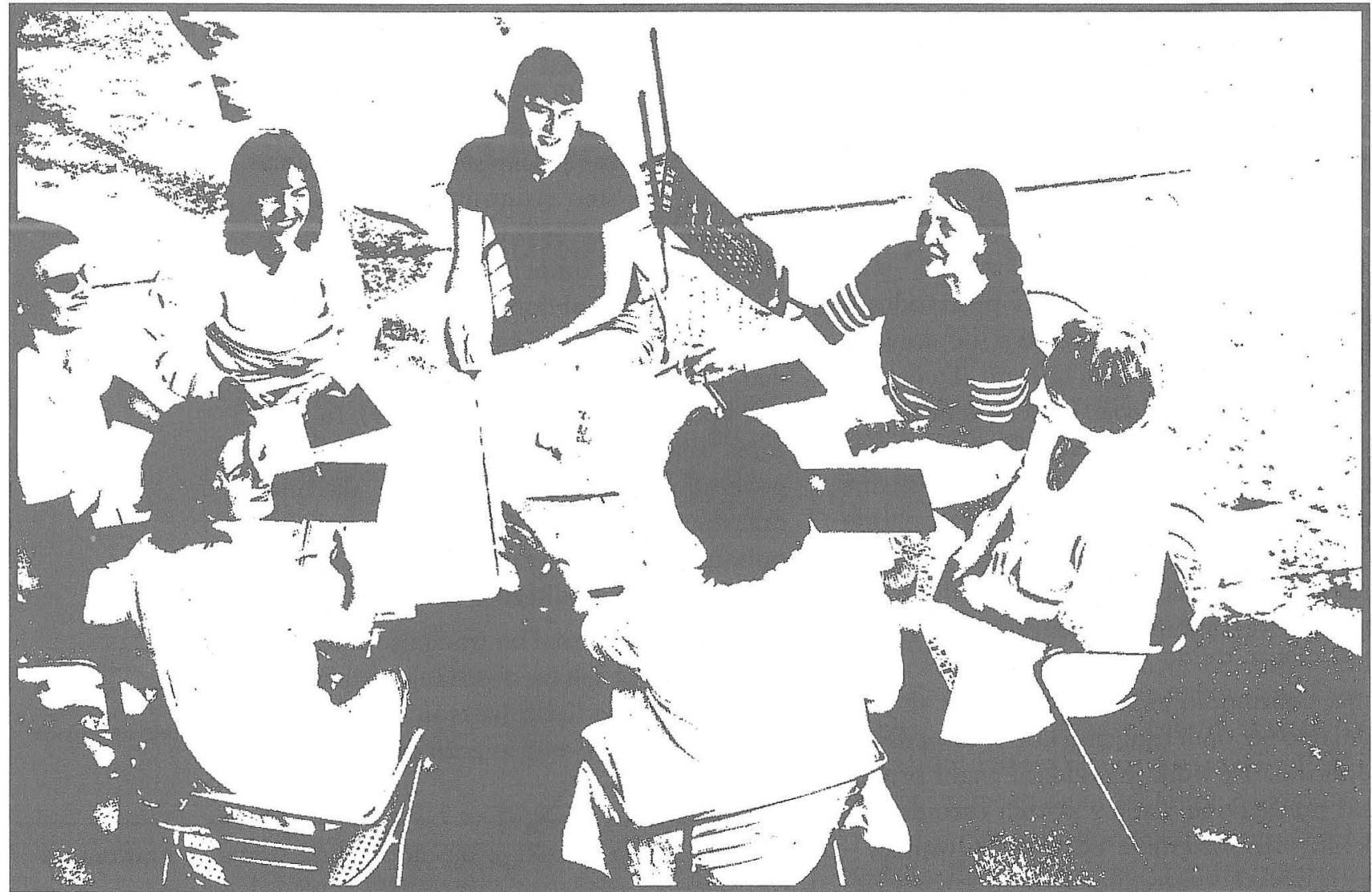

(težnje). To je izhodiščna točka, kajti to je tisto, kar jih povezuje kot državljane. To jim pomaga, da delujejo, skupno in povezano, $s$ ciljem, da bi stvari spremenili na bolje. V tem pogledu ni pomembno, katero »zares koristno znanje « nekaj velja, temveč kdo odloča o tem, kakšno znanje je nekaj vredno in kaj bodo z njim počeli.

Mirno lahko trdimo, da take skupine sestavljajo »epistemiološke skupnosti (Eyerman in Jamison,1991), kajti učenje odraslih se razvija znotraj in zunaj takšnih skupnosti; ustvarjajo družbena gibanja, kajti živijo v resničnem svetu, kjer se borijo za izhod izza učilničnih zidov in akademskih vrat. Še več, odnos izobraževanja odraslih do teh gibanj ima simbiotično osnovo. Tradicija izobraževanja odraslih za aktivno državljanstvo in politično angažiranost je vedno »visela « ne- kje v sredini med državo in cịvilno družbo, vključevala kolektivne izkušnje svojih študentov in jih spremenila ter preusmerila $\mathrm{v}$ družbeno in politično akcijo. Tako je postala vitalni instrument boja za razširitev demokracije. Vedno je bila tudi posrednica $\mathrm{v}$ razmerju med liberalno tradicijo državljanstva (kot je opisano), individualnim statusom in civilno republikansko tradicijo $\mathrm{dr}$ žavljanstva kot kolektivno uveljavljene družbene prakse (Lister, 1998). To je prostor, ki ga mora na novo politično definirana praksa izobraževanja odraslih ponovno zavzeti, če želi spodbujati in dajati oporo vseživljenjskemu učenju, za bolj dejavno, celostno obarvano in (po potrebi) nekonformistično opredelitev državljanstva. Na kratko, to, kar moramo storiti, je, da odraslega učenca kot političnega in družbenega akter- 
ja spravimo nazaj v vseživljenjsko učenje stališče, ki ga vedno molče zaobidejo v nenavadno ne-političnem diskurzu sodobne družbene teorije o kapitalu.

Možnost, da uporabimo temeljna načela izobraževanja odraslih za ustvarjanje povezave med vseživljenjskim učenjem, aktivnim državljanstvom in družbeno participacijo, je vzbudila med nekaterimi izobraževalci odraslih in izobraževalci za skupnost veliko zanimanje za sedanji vidik in proces "demokratičnega obnavljanja « na Škotskem (Crowther in drugi, 1999). Sedanji preobrat ustvarja možnosti - pa tudi probleme - za vse, ki se zanimajo za povezovanje političnega diskurza o aktivnem državljanstvu z izobraževalnim diskurzom o vseživljenjskem učenju in učečo se družbo. Zato je nujno, da ga vidimo v luči edinstvene priložnosti za ponovne stike izobraževalnega dela z izkušnjami, ki so jih dobili prebivalci Škotske v svojih skupnostih. Sedaj moramo najti poti, ki bi nam pokazale, kako se mora učeča se družba naučiti biti bolj demokratična in resnično dejavna družba. Ena od poti je, da se odločno postavimo proti ozko ekonomsko opredeljenemu diskurzu o državljanstvu, ki zadnja leta čedalje bolj prevladuje v teorijah o izobraževanju odraslih, politiki in raziskavah, in da jih dopolnimo s starejšim in bogatejšim diskurzom, ki pojmuje odraslega učenca kot družbenega in političnega akter$\mathrm{ja}$, in tako ponovno uveljavimo naše lastno delovanje v vlogi izobraževalca.

Izobraževanje odraslih vsebuje edinstven potencial za delovanje $\mathrm{v}$ vlogi katalizatorja med državljanstvom kot participacijo (delovanje $v$ okviru formalne politike $v$ državi) in državljanstvom kot članstvom (delovanje v okviru kulturne politike družbenih gibanj in civilne družbe). Izobraževanje odraslih lahko zelo jasno ustvari stik med učenjem in življenjem ter med formalno in stvarno strukturo državljanstva. To pa zahteva tako

pojmovan prostor, $\mathrm{v}$ okviru katerega lahko začnemo ponovno razmišljati, brati o teh zadevah in jih poučevati, pa tudi denarna sredstva (strokovnost, čas, denar). Le tako bo mogoče to uresničiti. To se mora zlasti zgoditi v marginalnih in osiromašenih skupnostih, kjer so prebivalci izgubili zaupanje $\mathrm{v}$ politični sistem - sistem, ki jih je zelo učinkovito pripravil do tega, da so postali nedejavni, s tem da jih je izključil iz članstva in jim preprečil vključevanje ter delovanje. Če ne bomo oblikovali takih izobraževal-

Odrasli učenci morajo znova najti vlogo družbenega in političnega akterja. nih razmer, ki bodo dovzetne za kritiko in ustvarjalne zamisli, ni nobene možnosti, da bi vseživljenjsko učenje uporabili za retoriko aktivnega državljanstva in ga spremenili $\mathrm{v}$ demokratično resničnost. 